\title{
Extraction and Analysis of Compounds with Antibacterial Potential from the Red Alga Grateloupia turuturu
}

\author{
Isabel Cardoso ${ }^{1}$, João Cotas ${ }^{1}{ }^{\mathbb{D}}$, Ana Rodrigues ${ }^{2}$, Daniel Ferreira ${ }^{2}$, Nádia Osório ${ }^{2,3}$ and \\ Leonel Pereira $1, *$ (D) \\ 1 MARE (Marine and Environmental Sciences Centre), Department of Life Sciences, Faculty of Sciences and \\ Technology, University of Coimbra, 3000-456 Coimbra, Portugal \\ 2 Coimbra Polytechnic Institute, ESTESC Coimbra Health School, Biomedical Laboratory Sciences, \\ 3046-854 Coimbra, Portugal \\ 3 Química-Fisica Molecular, Coimbra, 3004-535 Coimbra, Portugal \\ * Correspondence: leonel.pereira@uc.pt; Tel.: +351-239-240-782
}

Received: 16 June 2019; Accepted: 12 July 2019; Published: 15 July 2019

check for updates

\begin{abstract}
Nowadays, the development of new drugs only relies on a small number of molecules and $50 \%$ of all existent drugs are extracted or synthetically obtained. This work intends to evaluate the antibacterial potential of the ethanolic and polysaccharide extracts obtained from Grateloupia turuturu and to characterize the composition of the alga's polysaccharides by FTIR-ATR. We used sequential extraction to obtain the extracts that were tested against $S$. aureus and E. coli. The ethanolic extracts in E. coli, at the highest concentration used $\left(15 \mathrm{mg} \mathrm{mL}^{-1}\right)$ showed $45.7 \%$ (Tetrasporophyte extract) and $55.1 \%$ (Carposporophyte extract) of growth reduction and in S. aureus $56.2 \%$ (T extract) and $51.8 \%$ (C extract). Polysaccharide extracts started showing significant reduction effect on E. coli and S. aureus growth at $7.5 \mathrm{mg} \mathrm{mL}^{-1}$ with a reduction of $54.9 \%$ and $39.5 \%$, respectively. At $15 \mathrm{mg} \mathrm{mL}^{-1}$ the reduction observed was $88.5 \%$ and $85.4 \%$. The FTIR-ATR allowed to characterize G. turuturu's polysaccharides concluding that it is composed by a hybrid kappa/iota carrageenan with traces of agar, in both phases of the life cycle. This work allows us to conclude about the antibacterial properties of this alga and the compounds that might be behind this activity, showing that there's a lot more than a small number of molecules that can be used as natural drugs.
\end{abstract}

Keywords: Grateloupia turuturu; ethanolic extracts; polysaccharides extract; antibacterial properties; hybrid phycocolloid; polysaccharides characterization

\section{Introduction}

The interest in the exploitation of algae in the most varied areas (such as pharmaceuticals, nutraceuticals, food, and cosmetics) has been increasing since they are natural products with varied natural potentials that have not yet been studied. In this way, its study and its compounds become relevant.

Grateloupia turuturu (phylum Rhodophyta, class Florideophyceae, family Halymeniaceae) is a red macroalgae, commonly called "Devil's tongue weed" (in English), "Jinuari" (in Korean), and "Ratanho" (in Portuguese), originated in Asia [1]. It is currently spread across the globe, including Portugal [2].

It is characterized by having a flat and membranous stem and a short stipe. On the touch, its consistency varies between gelatinous and slippery, yet it has some firmness. Its color is between violet and red and can sometimes be greenish on top of the stem. The algae can reach about $50 \mathrm{~cm}$ in calm areas, with weak ripples and rich in nutrients. It has simple fronds that can be linear or broad-lanceolate that can arise whole or irregularly divided from the base broadening from this. 
Throughout the year the development of the algae is known to be variable and can be separated into three phases: The slow-growing phase (occurs in winter) with few variations in length, biomass, density and few differences in frond size, the fast-growing phase (occurs in spring-summer) with increased biomass, density and size differences and death phase (occurs at the end of the summer) [3].

It has two reproductive peaks in January and July, and its senescence period goes from July to September (months that record the highest temperatures) [3].

This species can be found both in protected areas and in areas exposed to rippling, although its growth is compromised by these conditions, presenting greater length in places with little ripple. It is an alga that tolerates great variations in temperature and salinity and manages to adapt well to eutrophic conditions. It is fixed in rocks located in "mid-intertidal" zones and is easy to find in pools [3].

Its recent distribution has been worrying the scientific community since it has some typical features of an invasive organism. In Portugal, G. turuturu can be found mostly in port areas like Porto de Leixões, Aveiro, and Figueira da Foz [3].

In [3] the dispersion processes were defined, namely: Primary dispersion that is favored by human activities, where there is a spatial discontinuity between the place of origin of the seaweed and the point where the new population settled (an example of what happens in Figueira da Foz port) and secondary dispersion in which there is dispersion in adjacent sites (justifies the entire northern zone).

It is believed that the propagation of this alga around the globe had as precursors the import of oysters and aquaculture activities [4].

In 2016, a work done in Portugal came to provide new insight into the behavior of this algae. In this study, the authors distinguish two types of non-native species, those that take advantage of ecological changes caused by human activities to establish (transient species) and those that lead to ecological changes (invasive species). It should be noted that the models are not mutually exclusive, and intermediate situations may occur. However, this bipartition enabled the researchers to conclude that G. turuturu did not have an invasive character as they did not detect any ecological changes caused by its presence, but rather a temporary character, not damaging the ecosystem (taking advantage of only one already fragile) [5].

About reproduction and development, this alga is monoecious, which means it has both male and female structures in the same individual. Its life cycle is annual and haplodiplontic, triphasic (gametophyte, carposporophyte, and tetrasporophyte) and isomorphic, which means, for one year, this seaweed will have one haploid life-cycle phase and two diploid life-cycle phases. The cycle is isomorphic between gametophyte phase and tetrasporophyte phase [4,6] (Figure 1). Fertile individuals occur all year long. One of the phases (carposporophyte) parasites another one (gametophyte, when fructified).

G. turuturu is also characterized by its richness in dietary fiber (nearly $60 \%$ dry weight $(\mathrm{dw})$ ) and therefore appears to be a good source of food fiber for human consumption [6]. This is of interest as the beneficial effect of fiber on health is already well-known. This seaweed is also rich in proteins, like Palmaria palmata, another red alga now authorized in France as a sea vegetable. Its lipid content is low, like all red seaweeds used in human nutrition, and its eicosapentaenoic acid content is similar to those reported for edible red seaweeds such as Chondrus cripus or Gracilariopsis longissima (as Gracilaria verrucosa) $[7,8]$.

About its chemical composition, G. turuturu is considered a good source of nutrients because of its protein content (red algae are the algae group with the highest levels of protein), and it is commercially used for carrageenan-production [9], its long chain polysaccharides (which constitute $49.8 \%$ of the algae's $\mathrm{dw}$ ). In this specific case, the type of polysaccharide is carrageenan, more specifically an agar-carrageenan hybrid polysaccharide known for showing anticoagulant activity [10]. These polysaccharides are found in cell walls and intercellular spaces of a large number of algae, mainly in red and brown algae [11]. In red algae, carrageenans are produced by the carrageenophytes (order Gigartinales), and the agar is produced by the agarophytes (several orders) [12]. Although carrageenan is produced specifically by red algae of the Gigartinales order, red algae of 
other orders can produce hybrid polysaccharides, such as G. turuturu. Although all the algae called carrageenophytes produce this polysaccharide, there are three distinct families of carrageenans (kappa family, iota family, and lambda family) [13], and therefore, not all carrageenophytes produce exactly the same type of polysaccharide.

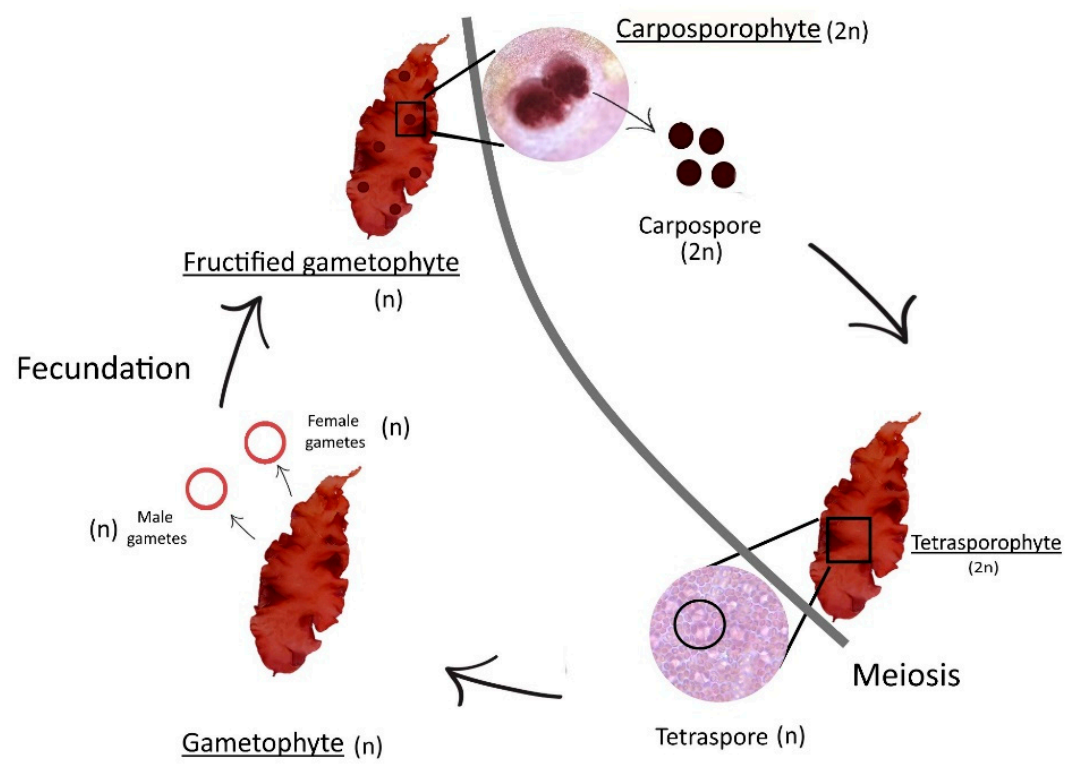

Figure 1. Grateloupia turuturu's life cycle. Its life cycle has three phases: Two isomorphic phases (Tetrasporophyte and Gametophyte) and a different phase (Carposporophyte) that parasites the gametophyte phase when fructified because this species is monoecious.

G. turuturu is also rich in vitamins such as $\mathrm{E}$ and $\mathrm{K}_{1}$ and holds high amounts of minerals $[7,14]$. It has a low lipid content [15] although the ones it possesses are important because they are not produced by the human body. Another compound produced by G. turuturu is R-phycoerythrin known as the main photosynthetic pigment of red algae [16]. Due to their high interest (since it can be used as a dye in fluorescence microscopy analyzes [17], some articles on this pigment specifically extracted from G. turuturu have already been written and their commercial value in 2013 was $€ 300 / \mathrm{mg}$ in France [18]. This alga also has fluridosid and isethionic acid that confers some non-stickiness, preventing crustaceans from attaching to the hulls of boats [19]. G. turuturu is used as food in China, in Japan, it is commonly used as a sea vegetable [20,21], and in Korea it is used in salads [22]. Moreover, it is considered an edible species in Portugal [7,23].

According to the literature, little is known about this species of the genus Grateloupia. Only one article about this alga reports its capacity to turn Vibrio parahemolyticus into a nonculturable state and the authors suggest that this capacity makes this alga a potentially ideal candidate to be integrated with animal culture to impair the propagation of any potential pathogenic bacteria [24].

However, positive results have already been observed regarding bioactivity against certain microorganisms of clinical and pharmacological interest in species of the same genus of this alga, as is the case of Grateloupia filicina whose extracts were shown to be capable against gram-positive and gram-negative bacteria such as Staphylococcus aureus, Escherichia coli and Pseudomonas aeruginosa [25] and against Bacillus subtilis [26]. In another article, this time about G. doryphora, the presence of antibacterial properties of its polar extracts against $S$. aureus was observed [27].

Considering the importance of marine organisms in the production of compounds with the most varied interests from the point of view both economic and ecological, and thus biotechnological, and taking into account the poor exploitation of algae in Portugal, the objectives of this work were to develop an easy way to describe the alga's life cycle, to adapt and develop a specific sequential extraction method, evaluate the antibacterial potential of the seaweed, compare the chemical composition between 
the two phases of the alga's life cycle (in the whole alga and in the polysaccharide extracts) and to identify some of its compounds of interest, namely in terms of its polysaccharides through FTIR-ATR analysis.

\section{Materials and Methods}

\subsection{Sampling of Grateloupia turuturu}

Specimens of Grateloupia turuturu Yamada were collected by hand in Buarcos Bay, Portugal, $\left(40^{\circ} 16^{\prime} \mathrm{N}, 8^{\circ} 90^{\prime} \mathrm{W}\right)$ in September 2018. Samples were washed with seawater filtered in the laboratory, in order to remove sands and salts. After that first wash, all samples were once again washed with distilled water and cleaned with paper to eliminate salts and epiphytes. Samples were then separated according to the different life cycle phases-tetrasporophytes and fructified gametophytes-using a magnifying glass. Tetrasporophytes exhibit simple and smooth blades and fructified gametophytes present prominent spherical cystocarps, producing carpospores (carposporophyte phase).

The biomass that was previously separated was stored in a hermetically sealed bag (duly identified with the alga name, picking date and phase) and then frozen at a temperature of about $-22{ }^{\circ} \mathrm{C}$ for further studies.

To begin the assays, first, the stored biomass was weighted and placed in Petri dishes (previously lined with parchment paper and well identified with the name of the seaweed, the date of harvest and the phase of the life cycle). Finally, they were placed in the oven to dry at a constant temperature of about $40^{\circ} \mathrm{C}$.

After drying, the samples were milled using a commercial mill (Taurus aromatic, Spain) and the dried powder $(<1 \mathrm{~mm})$ obtained was finally stored in sterile flasks (duly identified with the alga name, picking date and life cycle phase) in a dark and dry place at room temperature.

\subsection{Sequential Extraction of Compounds}

\subsubsection{Polar Compounds Extraction}

For sequential extraction, the ground dry material was weighted in a Kern scale and $5 \mathrm{~g}$ samples of the fructified gametophyte $(C)$ and tetrasporophyte $(T)$ phases, were made in triplicate $(n=3)$. The ground dry material ( $5 \mathrm{~g}$ ) was placed in ethanol (100 $\mathrm{mL}$ ethanol, $96 \%)$, at room temperature, for 1:30 $\mathrm{h}$, to extract the polar fraction. The solution was then filtered with a Gooch filter system with porosity $\mathrm{G}_{3}$, under vacuum. The ground dry material was recovered, and the process of extraction was repeated for another 1:30 $\mathrm{h}$. In the end, the polar solution filtered was evaporated in a rotary evaporator (Witeg, rotary evaporator model: 2600000, Germany) and stored, kept at $-22{ }^{\circ} \mathrm{C}$ until it could be lyophilized. The ground dry material was, once again, recovered for the next phase of the extraction.

\subsubsection{Polysaccharides Extraction}

The next and last phase had the purpose of carrageenan extraction, using the ground dry material recovered from the polar extraction. In this procedure, the ground dry material was placed in distilled water $(500 \mathrm{~mL})$ for $2 \mathrm{~h}$ after the water was boiling. In the end, the solution was hot filtered under vacuum, through a cloth filter. Once carrageenans had precipitated, by adding to the warm solution twice its volume of ethanol (96\%), they were dried at $40-50{ }^{\circ} \mathrm{C}$, for 24 to $48 \mathrm{~h}$ (modified protocol from [28]). Only the polysaccharides which were soon separated from the solution were recovered by using a rod and were placed in a 24-hour ethanol container at $-4{ }^{\circ} \mathrm{C}$ for further drying.

The dry carrageenans obtained previously were grounded and then stored in the dark, at room temperature until further use. 


\subsection{Extract Preparation}

Twelve samples were obtained for analysis corresponding to the two generations of the alga's life cycle, the two used solvents, and triplicates of each. The dried extracts were solubilized in water to a final concentration of $30 \mathrm{mg} \mathrm{mL}^{-1}$ for the ethanolic extracts and $20 \mathrm{mg} \mathrm{mL}^{-1}$ for the polysaccharide extracts.

To increase the solubilization power, it was necessary, after five minutes of homogenization, to subject the extracts to ultrasonic sonication (Ultrasons, PSelecta, Spain) for five minutes and then, to an incubation at $40^{\circ} \mathrm{C}$ for $5 \mathrm{~min}$. in a dry bath and subsequent ultrasonic sonication for another $5 \mathrm{~min}$. A second homogenization was made for another $5 \mathrm{~min}$. followed by centrifugation at $8000 \times g$ for $2 \mathrm{~min}$. The soluble contents were separated and stored.

\subsection{Sterility Control of the Extracts}

To analyze the sterility of the extracts, $10 \mu \mathrm{L}$ of each extract was then withdrawn and then inoculated into Mueller-Hinton broth medium (Merck, Germany), incubated at $35^{\circ} \mathrm{C}$ for $24 \mathrm{~h}$. After this time, each suspension was inoculated in trypticase soy agar (TSA) (Prolabo, Belgium) medium incubated at $24-35 \pm 2{ }^{\circ} \mathrm{C}$ with subsequent observation of absence or presence of growth. The extracts that presented some type of contamination were eliminated.

\subsection{Strains}

To test the antibacterial properties of the extracts the following strains were used: Escherichia coli ATCC 8739, Staphylococcus aureus ATCC 25923 (American Type Culture Collection, Rockville, MD).

The strains were cryopreserved and grown in trypticase soy broth (TSB, Merck, Germany) overnight at $35 \pm 2{ }^{\circ} \mathrm{C}$ and then the grown bacterial suspensions were inoculated in TSA for isolated and pure colonies.

\subsection{Microdilution Assay}

In the microdilution technique, we used MHB (Muller-Hinton broth) and add fixed concentrations of $7.5,10,12.5$, and $15 \mathrm{mg} \mathrm{mL}^{-1}$ for ethanolic (polar) and polysaccharide extracts. To test the bioactivity of the extracts, bacteria were suspended in saline to $0.5 \mathrm{McF}$ arland. This way, a final concentration of bacteria of $1 \times 10^{6} \mathrm{CFU} \mathrm{mL} \mathrm{m}^{-1}$ was added to every well. We also made a positive and negative control, and everything was done in duplicate. The incubation period was $24 \mathrm{~h}$ at $37 \pm 2{ }^{\circ} \mathrm{C}$.

The cytotoxicity was evaluated using 95\% Iodonitrotetrazolium chloride solution (INT) at $0.5 \mathrm{mg} \mathrm{mL}^{-1}$. Thus, it became possible to detect the number of viable cells in the sample through the metabolism of INT whose initial color is yellow and, when metabolized by the living microorganisms, changes to pink/purple. For this metabolization process to be visible, the incubation was carried out for $30 \mathrm{~min}$ at $37 \pm 2{ }^{\circ} \mathrm{C}$. The microplates were then read at $570 \mathrm{~nm}$ and then the $\%$ viable cells were determined, using the following formula [29]:

$$
\frac{\% \text { of Viable cells }=(\text { M.O.D extract with strain }- \text { M.O.D extract })}{\text { M.O.D strain }- \text { M.O.D culture medium })} \times 100
$$

Equation explained:

M.O.D extract with strain: Mean of the optical density of the two readings obtained by spectrophotometric measurement at $570 \mathrm{~nm}$ after incubation of the extract at a given concentration and the MHB strain.

M.O.D extract: Mean of the optical density of the two readings obtained by spectrophotometric measurement at $570 \mathrm{~nm}$ after incubation of the extract at a given concentration in MHB.

M.O.D strain: Mean of the optical density of the two readings obtained by spectrophotometric measurement at $570 \mathrm{~nm}$ after incubation of the strain in MHB. 
M.O.D culture medium: Mean of the optical density of the two readings obtained by spectrophotometric measurement at $570 \mathrm{~nm}$ after incubation of MHB.

\subsection{Statistical Analysis}

The data was introduced and analyzed using GraphPad Prism software version 7.04 for Windows (GraphPad Software, San Diego, CA, USA), relating the variables in the study using the two-way ANOVA statistical test associated with the Bonferroni test with multiple comparisons. Differences were considered significant when $p$-value $<0.05$.

\subsection{Analysis of Dry Biomass and Polysaccharide Extracts of G. turuturu by FTIR-ATR}

\subsubsection{Collection and Treatment of Samples}

For FTIR-ATR analysis (Fourier transform infrared spectroscopy, attenuated total reflectance), we used the dried biomass of the whole alga that was separated by the two phases (tetrasporophyte and fructified gametophyte) and those samples were milled using a commercial mill (Taurus aromatic, Spain) to obtain a fine powder, which was subjected to direct analysis [30-32].

We also analyzed, by FTIR-ATR, the polysaccharide obtained by sequential extraction, after being milled, using the same technique as for the entire alga.

\subsubsection{FTIR-ATR Analysis}

The FTIR-ATR analysis we made is a method of infrared spectroscopy, widely used to study and characterize phycocoloids (among other compounds) present in algae and was based on the protocol described in [33].

The apparatus used was the IFS 55 spectrometer, using the Golden Gate single reflection Diamond ATR system with acquisitions from 0 to $4000 \mathrm{~cm}^{-1}$. However, only the wavelengths between 500 and $1500 \mathrm{~cm}^{-1}$ are relevant for the analysis and characterization of polysaccharides.

From FTIR-ATR analysis, four spectra were obtained (two of them from the thallus analysis separated by generation, and the other two from the polysaccharides analysis also separated by generation). These spectra were then compared, and their peaks were analyzed in order to identify the compounds that constitute the polysaccharides of G. turuturu. To do so, it was important to use four references $[30,31,33,34]$ to identify the bands and the corresponding bonds/groups type present in the colloid molecules.

\section{Results}

\subsection{Microdilution Assay and Cytotoxic Analysis}

\subsubsection{Escherichia coli}

Regarding the antimicrobial activity of the polar extracts (for both phases Tetrasporophyte and Carposporophyte) in the presence of E. coli, it was found that there is a gradual reduction of growth. As the concentration increases the activity also increases. At a concentration of $10 \mathrm{mg} \mathrm{mL}^{-1}$ the $\mathrm{T}$ extract showed a statistically significant reduction of growth of $20.49 \%$ (\% viable cells in T 10: $79.51 \pm$ $3.72, p \leq 0.05$ ). At higher concentrations a reduction in bacterial growth occurred in both extracts ( $\mathrm{T}$ and C) showing at a $12.5 \mathrm{mg} \mathrm{mL}^{-1}$ a reduction of $26.33 \%$ in the $\mathrm{T}$ extract and a reduction of $33.19 \%$ in the $\mathrm{C}$ extract (\% viable cells in T 12.5: $73.67 \pm 6.23, p \leq 0.01$ \% viable cells in C 12.5: $66.81 \pm 10.59, p \leq 0.001$ ). At the highest concentration of $15 \mathrm{mg} \mathrm{mL}^{-1}$ the results show a $45.7 \%$ and $55.1 \%$ growth reduction, respectively (\% viable cells in T 15: $54.3 \pm 10.64$, \% viable cells in C 15: $44.9 \pm 4.73$ ), this reduction being statistically significant $(p \leq 0.001)$ (Figure 2 ). 


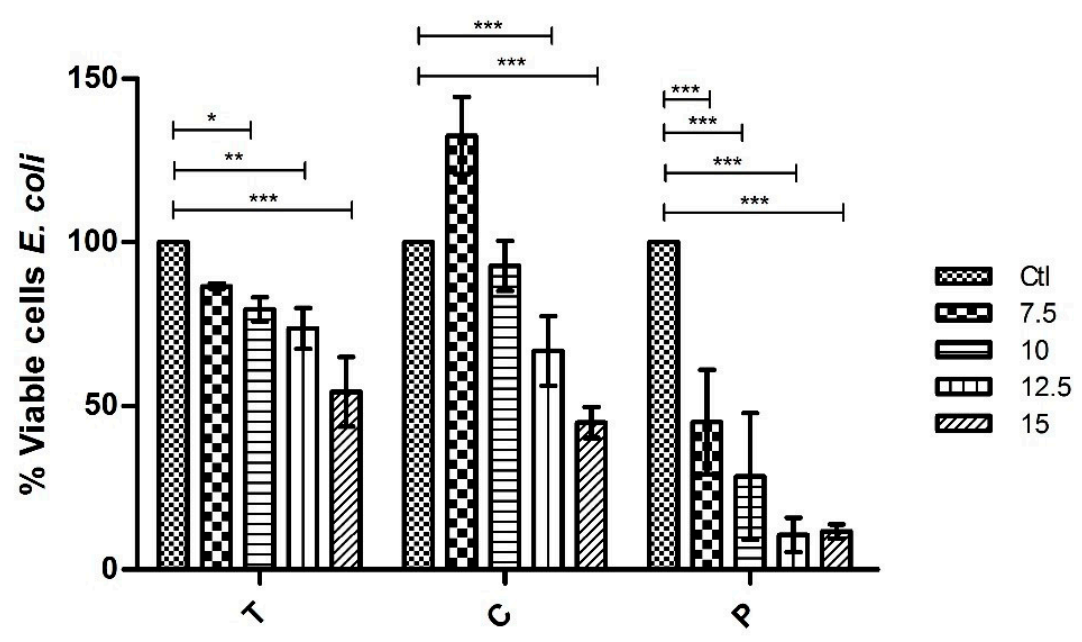

Figure 2. Cytotoxicity assay for E. coli with polar and polysaccharide extracts. T: Polar extract from Tetrasporophyte phase, C: Polar extract from Fruited gametophyte phase, P: Polysaccharide extract from Fruited gametophyte. The concentration units are in $\mathrm{mg} \mathrm{mL}^{-1}$.

The polysaccharide extracts started showing significant reduction effect on $E$. coli growth at a concentration of $7.5 \mathrm{mg} \mathrm{mL}^{-1}$ with a reduction of $54.96 \%$ (\% viable cells in P 7.5: $45.04 \pm 16.03$ ) At higher concentrations $\left(10 \mathrm{mg} \mathrm{mL}^{-1}, 12.5 \mathrm{mg} \mathrm{mL}^{-1}\right.$ and $\left.15 \mathrm{mg} \mathrm{mL}^{-1}\right)$, the growth was gradually reduced, with reductions of $71.53 \%, 89.43 \%$ and $88.46 \%$ (\% viable cells in P 10: $28.47 \pm 19.28$, in P 12.5: 10.57 \pm 5.29 , in $\mathrm{P} 15: 11.64 \pm 2.23$ ). Thus, showing that, like the ethanolic extracts, as the concentration increases the activity against the strain increases. Each growth reduction has statistical significance $(p \leq 0.001)$ (Figure 2).

\subsubsection{Staphylococcus aureus}

Regarding the antimicrobial activity of the polar extracts (for both phases $\mathrm{T}$ and $\mathrm{C}$ ) in the presence of $S$. aureus, it was possible to observe some gradual reduction of growth starting at the concentration of $10 \mathrm{mg} \mathrm{mL}^{-1}$ with a significant reduction of $31.7 \%$ and $37.1 \%$, respectively, (\% viable cells in T 10: 68.3 \pm 2.83 , in C 10: $62.9 \pm 16.9$ ), meaning that the higher the extract concentration the better the reduction of growth. At higher concentrations, the results were even more noticeable. At a concentration of $12.5 \mathrm{mg} \mathrm{mL}^{-1}$ the results show a reduction of growth of $46.5 \%$ and $45.1 \%$ for $\mathrm{T}$ and $\mathrm{C}$ extracts respectively (\% viable cells in T 12.5: $53.5 \pm 3.57$, in C 12.5: $54.9 \pm 10.68$ ) and at the highest concentration $\left(15 \mathrm{mg} \mathrm{mL}^{-1}\right)$ the growth reduction was $56.19 \%$ in T extract (\% viable cells in T 15: $\left.43.81 \pm 1.55\right)$ and $51.81 \%$ in C extract (\% viable cells in C 15: $48.19 \pm 13.7$ ). In all of these cases, these values represent statistical significance $(p \leq 0.001)$ (Figure 3 ).

The polysaccharide extract against this strain started showing significant results at a concentration of $7.5 \mathrm{mg} \mathrm{mL}^{-1}$ with a reduction of growth of $39.46 \%$ (\% viable cells in P 7.5: $60.54 \pm 11.58$ ). In this case, it was also possible to observe gradual reduction of growth being that at a concentration of $10 \mathrm{mg} \mathrm{mL}^{-1}$ there was a reduction of $58.44 \%$ (\% viable cells in P 10: $41.56 \pm 17.61$ ), at a concentration of $12.5 \mathrm{mg} \mathrm{mL}^{-1}$ the reduction was of $76.87 \%$ (\% viable cells in P 12.5: $23.13 \pm 2.02$ ) and at the highest concentration the reduction was of $85.44 \%$ (\% viable cells in P 15: $14.56 \pm 3.25)$. Showing, once again, that when we increased the extract concentration, the reduction of growth also increases. These values represent statistical significance $(p \leq 0.001)$ (Figure 3). 


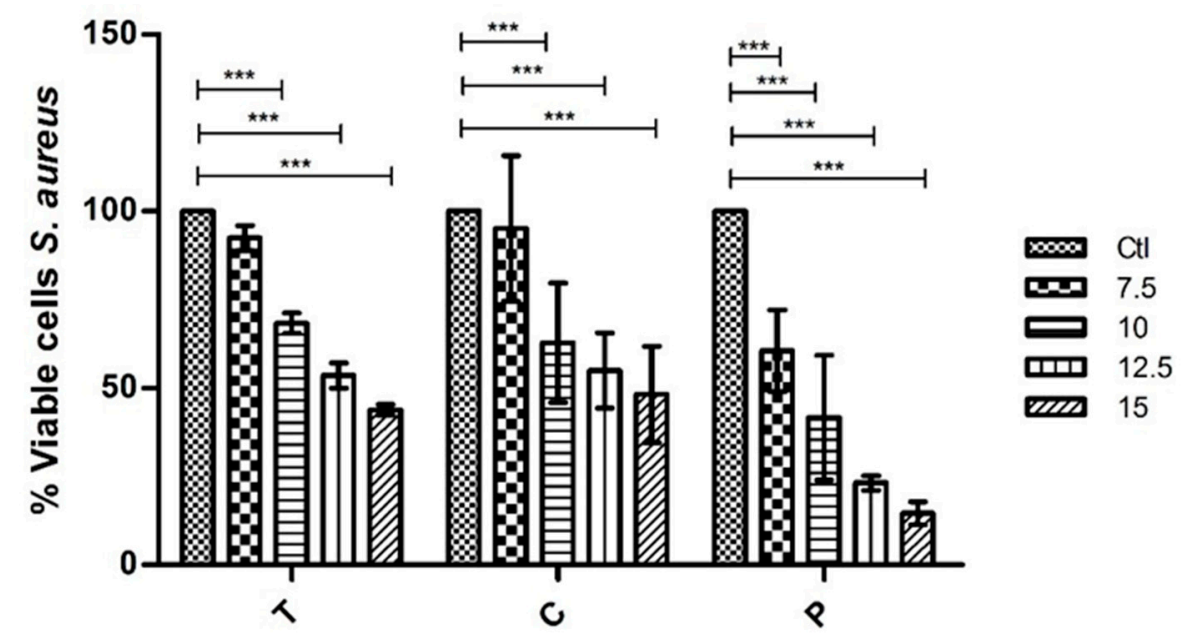

Figure 3. Cytotoxicity assay for S. aureus with ethanolic and polysaccharide extracts. T: Polar extract from Tetrasporophyte phase, C: Polar extract from Fruited gametophyte phase, P: Polysaccharide extract from Fruited gametophyte. The concentration units are in $\mathrm{mg} \mathrm{mL}^{-1}$.

\subsection{Analysis of the Biomass and Polysaccharide Extracts of G. turuturu by FTIR-ATR}

The polysaccharide extracts and the dried samples of Grateloupia turuturu, in the two phases, were analyzed by vibrational spectroscopy to identify the colloids presents in the alga (Figure 4).

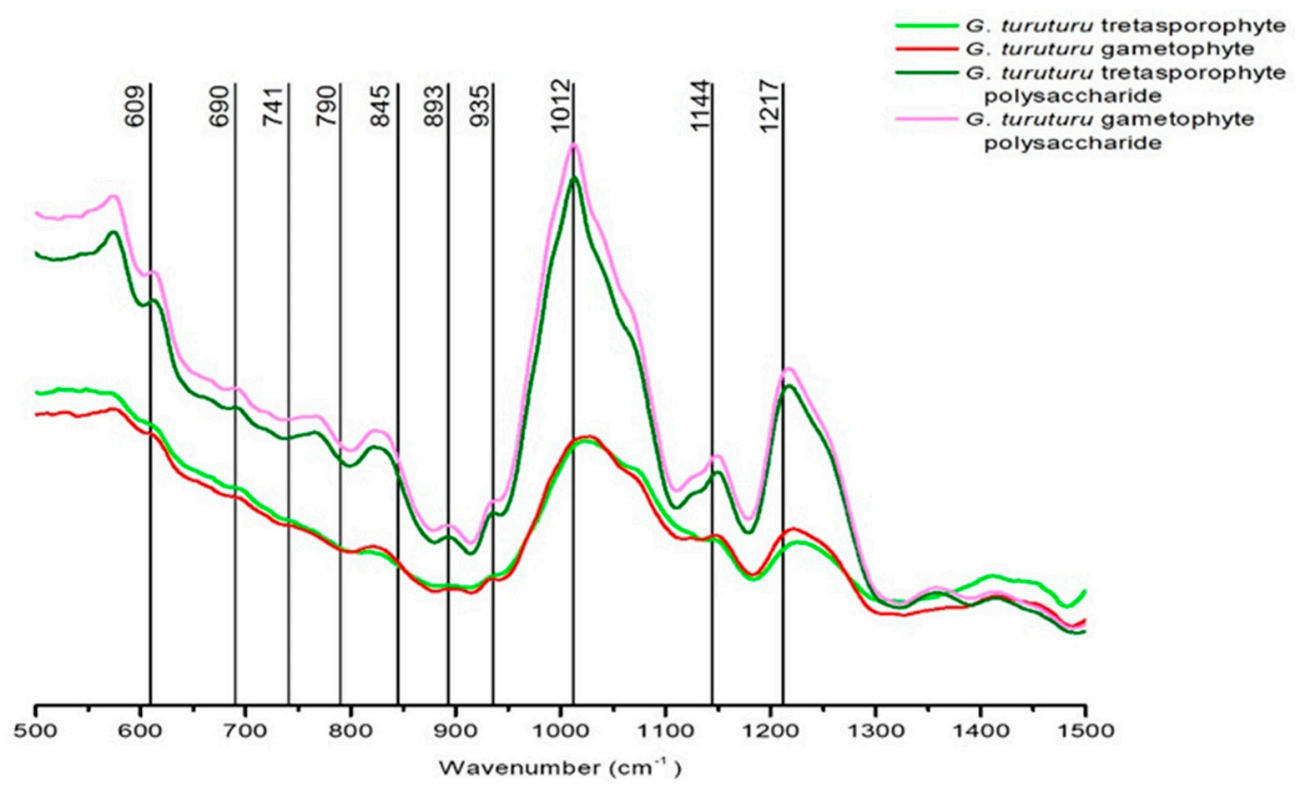

Figure 4. FTIR-ATR spectra from dried seaweed ("G. turuturu tetrasporophyte" and "G. turuturu gametophyte") and polysaccharide extracts ("G. turuturu tetrasporophyte polysaccharide" and G. turuturu gametophyte polysaccharide") from G. turuturu.

The spectra of FTIR-ATR showed the same peaks and mean values between the two different phases, noting that the colloid does not have changes between them.

The thalli of G. turuturu (whole alga) analyzed in this study demonstrated that the two phases (carposporophyte and tetrasporophyte) have the same colloid type (Table 1). The bands present in the spectra highly support the presence of a hybrid kappa/iota/theta carrageenan with some vestigial presence of agar. 
Table 1. FTIR analysis of the dried seaweed and colloid extracts from G. turuturu.

\begin{tabular}{|c|c|}
\hline Wavelength Numbers $\left(\mathrm{cm}^{-1}\right)$ & Bonds/Assignments \\
\hline 609 & C-S stretching vibrations (agar) \\
\hline 690 & 3,6- anhydro-L-galactose (agar) \\
\hline 741 & C-S/C-O-C bending mode in glycosidic linkages of agars \\
\hline 790 & Characteristic of agar-type in second derivative spectra \\
\hline 845 & the D-galactose-4-sulfate (G4S) \\
\hline 893 & 3,6-anhydro-D-gactose-2-sulfate (DA2S) (agar/carrageenan) \\
\hline 935 & C-O of 3,6-anhydrogalactose (DA) (agar/carrageenan) \\
\hline 1012 & $\mathrm{~S}=\mathrm{O}$ (sulphated esters) \\
\hline 1144 & $\mathrm{~S}=\mathrm{O}$ (sulphated esters) \\
\hline 1217 & $\mathrm{~S}=\mathrm{O}$ (sulphated esters) \\
\hline
\end{tabular}

\section{Discussion}

The search for new molecules with antimicrobial potential is not recent. Over time, there has been an increasing need to find compounds (especially natural compounds) that will respond to problems such as the dispersion of multiresistant microorganisms or to situations of diseases whose treatment or cure is difficult or non-existent. In addition, in the most varied areas (cosmetics, pharmaceuticals, nutraceuticals or even food), there is a constant search for new products that will respond to trends and/or improve people's quality of life. On the other hand, the use of algae in traditional medicine has always been recognized as first instance treatment for certain problems and, because it is an empirical knowledge, in many cases the mechanisms behind the effect they present are still not perceptible [35].

This work was divided into three important parts, being the first one the bioassays where extracts of G. turuturu were tested against $S$. aureus and E. coli to determine its capacity to inhibit the bacterial growth, the second one being the comparison, by FTIR-ATR and through the bioassays, of the compounds presents in two different phases of the life cycle of the alga and the third one the FTIR-ATR analyze to better characterize the alga's polysaccharides and relate its composition with the eventual bioactivity observed against the bacteria.

From the extracts tested of G. turuturu corresponding to extractions with different solvents and separated by the phases of their life cycle (tetrasporophyte generation and fruited gametophyte), it is to be noted that at the concentrations tested none of the extracts eliminates the strains used. However, it was verified that some of the extracts have antimicrobial capacity reducing their growth significantly. Moreover, it was possible to observe a gradual reduction of growth of these two bacteria when in the presence of the extracts. Thus, showing that the higher the concentration of the extract, the less the bacteria grow. For the polar part (with ethanolic extracts) of the bioassay, two extracts were tested, one for each phase of the life cycle ( $\mathrm{T}$ and $\mathrm{C})$. When tested against $E$. coli, at the highest concentration of $15 \mathrm{mg} \mathrm{mL}^{-1}$ the results show a $45.7 \%$ and $55.1 \%$ growth reduction, respectively. Whereas, against $S$. aureus at the highest concentration the growth reduction was $56.2 \%$ in $\mathrm{T}$ extract and $51.8 \%$ in C extract. That allows us to conclude that the differences between phases of the life cycle are not relevant and that the polar compounds in the composition of the ethanolic extract have, in fact, some interesting antibacterial capacity.

In similar studies, the authors have already described some compounds usually present in this type of polar extracts, namely, fatty acids (palmitoleic acid, oleic acid), glycosides and alkaloids, that are associated in fact with the antibacterial capacity observed against these two strains [25,36,37]. In a study of other algae of the same genus Grateloupia (G. livida), similar results have also been described [38].

The results obtained with the polysaccharides extracts also show a gradual reduction of bacterial growth. In this case, only the polysaccharides of one of the phases of the life cycle were tested (C phase or fruited gametophyte phase). For E. coli, promptly at $7.5 \mathrm{mg} \mathrm{mL}^{-1}$, the results show significant inhibition of growth (reduction of $54.9 \%$ ). At the highest concentrations of $12.5 \mathrm{mg} \mathrm{mL}^{-1}$ and $15 \mathrm{mg}$ $\mathrm{mL}^{-1}$ the reduction was of $89.4 \%$ and $88.5 \%$, respectively. Thus, showing that the inhibit of growth is almost total. In the S. aureus case, at the lowest concentration of $7.5 \mathrm{mg} \mathrm{mL}^{-1}$ the reduction was 
only of $39.5 \%$ but as the concentration of the extract got higher the reduction of growth was gradually getting higher too as such that at the maximum concentration of $15 \mathrm{mg} \mathrm{mL}^{-1}$ the reduction was $85.4 \%$. This led us to conclude that polysaccharides have an interesting capacity to inhibit the growth of these two bacterial strains and, in that case, there is a need to study and try to better understand their composition.

Based on these results, it is important to mention that the total concentration of polysaccharides in algae varies from $4 \%$ to $76 \%$ of their dry weight, some of which present biological activity such as carrageenans and fucans [7]. It is also known that the main component of red algae (Gigartinales) is carrageenan (long chain sulfated polysaccharides) and that these are already associated with the inhibitory capacity against various microorganisms such as E. coli and S. aureus [25,39-41].

When comparing the bioactivity of the extracts of G. turuturu to extracts of other similar or phylogenetically close algae against the same bacterial strains, it is possible to observe variations in the results obtained, either in concentration or inhibitory effect. Several factors contribute to these differences, ranging from the variation of compounds among individuals of the same species of alga, but in which the time of the year of harvest was different, variation of compounds between algae although evolutionarily close (such as algae of the same genus, but that do not exhibit the same inhibitory results, or cases in which bioactivity between red algae is compared). It is also necessary to consider the location and time of harvesting of algae, since abiotic factors (climate, location, salinity, temperature, and other stressors) may influence the production and concentration of bioactive compounds [25].

Since the best results with the bioassays were presented by the polysaccharide extracts, we used the FTIR-ATR analyze where we were able to observe spectra from G. turuturu thalli (whole alga) and its colloid (polysaccharides). With those spectra, it was possible to characterize the polysaccharides and conclude that the bands present in the spectra highly support the presence of sulfated esters and the presence of a hybrid kappa/iota/theta carrageenan with some vestigial presence of agar. This information corroborates what has already been reported about G. turuturu and its similarities with other species of the same genus, G. filicina, which have already been characterized by having agar in its composition [7].

Some studies had already confirmed the presence of kappa and iota hybrid carrageenan in $G$. turuturu $[42,43]$ and some others also detected the presence of cellulose and agar in the cell wall of the alga [44]. Still, in the discussion of an article [7], there were presented some studies that point out the presence of agar in the genus Grateloupia and suggest that G. turuturu produces a hybrid polysaccharide of carrageenan with a small fraction of agar.

Although antibacterial or antifungal properties of agar (a distinct feature of this carrageenophyte genus) are not known, the results obtained in the bioassays are not without corroboration by FTIR-ATR analysis since in the carrageenans identified in this alga there are already known properties regarding the inhibitory capacity against certain bacteria and fungi [7,39-41]. In addition, the importance of the sulfated esters composition to confer bioactivity is known [45], so the inhibitory capacity of this alga can be justified by the present bands, where several sulfate esters can be identified.

In the future it would be interesting to obtain extracts with higher concentrations (namely polar and polysaccharide extracts), it would also be interesting to test other bacteria and some fungi with different morphological characteristics, but also virulence and resistance. As well as analyzing and identifying the polar compounds present in extracts by FTIR-ATR or other techniques.

\section{Conclusions}

Before this work, there was a need to improve the understanding of the life cycle of Grateloupia turuturu and, also, a need to optimize the sequential extraction method for this specie. Furthermore, it was our intention to test the bioactivity of this alga's compounds and to characterize them. 
So, this work provides, for the first time, an explanatory image of Grateloupia turuturu's life cycle and an adapted protocol for the sequential method that was used in order to obtain ethanolic and polysaccharide extracts.

Regarding its bioactivity, this work allows us to conclude that this alga has some interesting compounds with pharmaceutical interest, since it was possible to observe, both in the ethanolic extracts and polysaccharides extracts, the capacity to inhibit the growth of two different bacterial strains. In the assays with E. coli, a $55.1 \%$ of growth reduction in the presence of the ethanolic extract and $89.43 \%$ of growth reduction in the presence of the polysaccharide extract were observed. In the assays with $S$. aureus, a $56.19 \%$ of growth reduction in the presence of the ethanolic extract and $85.44 \%$ of growth reduction in the presence of the polysaccharide extract were observed.

From the analysis of the dried biomass by FTIR-ATR, it is possible to observe the presence and high concentration of sulfated esters (that are already known for its bioactive role and can corroborate our bioassay results). Moreover, we can conclude that G. turuturu has a hybrid kappa/iota/theta carrageenan with some vestigial presence of agar. The existence of agar in a carrageenophyte is not without interest since agar is common in agarophytes and not in carragenophytes.

With this work, the antibacterial potential of G. turuturu was widely exploited for the first time especially with the bioassays where polysaccharide extracts were tested against two bacterial strains (one $\mathrm{Gram}^{+}$and the other one $\mathrm{Gram}^{-}$), also it was the first time that this alga's polar extracts where tested against $E$. coli. Another novelty with this work was the comparison of the chemical composition between two phases of the alga's life cycle, namely when compared its bioactivity and when analyzed by FTIR-ATR. Lastly, it was the first time that the dried sample of the whole alga was analyzed by FTIR-ATR in order to characterize its polysaccharides and its composition.

It is worth noting the need for continuity of this study, as well as to evaluate other properties such as antioxidants, anticancer, among others, which may be of extreme importance in areas such as health and nutrition.

In the future, we think it is important to characterize the ethanolic extract with HPLC, supported with a more detailed assay of FTIR-ATR in order to get more information about this alga and describe the compounds present in G. turuturu that can justify its bioactivity.

Author Contributions: For this research article the specifying of the individual contributions of the authors is as follows: conceptualization, I.C., J.C., N.O. and L.P.; methodology, I.C., J.C., N.O. and L.P.; investigation, I.C., A.R. and D.F.; resources, N.O. and L.P.; writing-original draft preparation, I.C.; writing-review and editing, I.C., J.C., N.O., and L.P.; visualization, I.C.; supervision, N.O. and L.P.; project administration, N.O. and L.P.; funding acquisition, N.O. and L.P.

Funding: This work was supported by the Fundação para a Ciência e a Tecnologia (FCT), through the strategic project UID/MAR/04292/2019 granted to MARE. We also received funding from European Structural and Investment Funds through the COMPETE Programme and from National Funds through FCT-Fundação para a Ciência e a Tecnologia under the Programme grant SAICTPAC/0019/2015 and Interreg project NASPA.

Acknowledgments: The authors thank Paulo Ribeiro Claro (CICECO, University of Aveiro, Portugal) for obtaining the FTIR-ATR spectra.

Conflicts of Interest: The authors declare no conflict of interest.

\section{References}

1. Pereira, L.; Neto, J.M. Marine Algae Biodiversity, Taxonomy, Environmental Assessment, and Biotechnology, 1st ed.; CRC Press, Taylor \& Francis Group: Boca Raton, FL, USA, 2014.

2. ICES (2006) Working Group on Introductions and Transfers of Marine Organisms (WGITMO). ICES CM 2006/ACME:05. Available online: http://ices.dk/sites/pub/Publication\%20Reports/Expert\%20Group\% 20Report/ACME/2006/ACME0506.pdf (accessed on 13 July 2019).

3. Araújo, R.; Violante, J.; Pereira, R.; Abreu, H.; Arenas, F.; Sousa-Pinto, I. Distribution and population dynamics of the introduced seaweed Grateloupia turuturu (Halymeniaceae, Rhodophyta) along the Portuguese coast. Phycologia 2011, 50, 392-402. [CrossRef] 
4. Verlaque, M.; Brannock, P.M.; Komatsu, T.; Villalard-Bohnsack, M.; Marston, M. The genus Grateloupia C. Agardh (Halymeniaceae, Rhodophyta) in the Thau lagoon (France, Mediterranean): A case study of marine plurispecific introductions. Phycologia 2005, 44, 477-496. [CrossRef]

5. Mulas, M.; Bertocci, I. Devil's tongue weed (Grateloupia turuturu Yamada) in northern Portugal: Passenger or driver of change in native biodiversity? Mar. Environ. Res. 2016, 118, 1-9. [CrossRef] [PubMed]

6. Umezaki, I. Life history types of the florideophyceae (Rhodophyta) and their evolution. Publ. Seto Mar. Biol. Lab. 1989, 34, 1-24. [CrossRef]

7. Rodrigues, D.; Freitas, A.C.; Pereira, L.; Rocha-Santos, T.A.P.; Vasconcelos, M.W.; Roriz, M.; Rodríguez-Alcalá, L.M.; Gomes, A.M.P.; Duarte, A.C. Chemical composition of red, brown and green macroalgae from Buarcos Bay in Central West Coast of Portugal. Food Chem. 2015, 183, 197-207. [CrossRef] [PubMed]

8. Fleurence, J.; Gutbier, G.; Mabeau, S.; Leray, C. Fatty acids from 11 marine macroalgae of the French Brittany coast. J. Appl. Phycol. 1994, 6, 527-532. [CrossRef]

9. Braune, W.; Guiry, M. Seaweeds-A colour guide to common benthic green. In Brown and Red Algae of the World's Oceans; ARG Gantner Verlag KG: Ruggell, Liechtenstein, 2011; p. 601.

10. Efimov, V.S.; Usov, A.I.; Ol'skaya, T.S.; Baliunis, A.; Roskin, M.Y. Comparative study of anticoagulant activity of sulfated polysaccharides obtained from red sea algae. Farmakol. Toksikol. 1983, 46, 61-67.

11. Cardozo, K.H.; Guaratini, T.; Barros, M.P.; Falcão, V.R.; Tonon, A.P.; Lopes, N.P.; Campos, S.; Torres, M.A.; Souza, A.O.; Colepicolo, P.; et al. Metabolites from algae with economical impact. Comp. Biochem. Physiol. C 2007, 146, 60-78. [CrossRef]

12. Chopin, T.; Kerin, B.F.; Mazerolle, R. Phycocolloid chemistry as a taxonomic indicator of phylogeny in the Gigartinalis, Rhodophyceae: A review and current developments using Fourier transform infrared diffuse reflectance spectroscopy. Phycol. Res. 1999, 47, 167-198. [CrossRef]

13. Pangestuti, R.; Kim, S. An Overview of Phycocolloids: The principal commercial. In Marine Algae Extracts: Processes, Products, and Applications; Kim, S.K., Chojnacka, K., Eds.; Wiley-VCH: Weinheim, Germany, 2015; pp. 319-330.

14. Lordan, S.; Ross, R.P.; Stanton, C. Marine bioactives as functional food ingredients: Potential to reduce the incidence of chronic diseases. Mar. Drugs 2011, 9, 1056-1100. [CrossRef]

15. Kendel, M.; Wielgosz-Collin, G.; Bertrand, S.; Roussakis, C.; Bourgougnon, N.B.; Bedoux, G. Lipid composition, fatty acids and sterols in the seaweeds Ulva Armoricana, and Solieria Chordalis from Brittany (France): An analysis from nutritional, chemotaxonomic, and antiproliferative activity perspectives. Mar. Drugs 2015, 13, 5606-5628. [CrossRef] [PubMed]

16. Denis, C.; Morançais, M.; Li, M.; Deniaud, E.; Gaudin, P.; Wielgosz-Collin, G.; Barnathan, G.; Jaouen, P.; Fleurence, J. Study of the chemical composition of edible red macroalgae Grateloupia Turuturu from Brittany (France). Food Chem. 2010, 119, 913-917. [CrossRef]

17. Fleurence, J. R-phycoerythrin from red macroalgae: Strategies for extraction and potential application in biotechnology. Appl. Biotechnol. Food Sci. Policy 2003, 1, 63-68.

18. Munier, M.; Dumay, J.; Morançais, M.; Jaouen, P.; Fleurence, J. Variation in the biochemical composition of the edible seaweed Grateloupia turuturu Yamada harvested from two sampling sites on the Brittany Coast (France): The influence of storage method on the extraction of the seaweed pigment r-phycoerythrin. J. Chem. 2013, 2013, 1-8. [CrossRef]

19. Simon-Colin, C.; Bessières, M.A.; Deslandes, E. Characterization of N-methyl-methionine sulfoxide and isethionic acid from the red alga Grateloupia doryphora. Phycol. Res. 2002, 50, 125-128. [CrossRef]

20. Bangmei, X.; Abbott, I. Edible seaweeds of China and their place in the Chinese diet. Econ. Bot. 1987, 41, 341-353. [CrossRef]

21. Fujiwara-Arasaki, T.; Mino, N.; Kuroda, M. The protein value in human nutrition of edible marine algae in Japan. Hydrobiologia 1984, 116, 513-516. [CrossRef]

22. Sohn, C.H. The seaweed resources of Korea. In Seaweed Resources of the World; Critchley, A.T., Ohno, M., Largo, D.B., Gillespie, R.D., Eds.; Japan International Cooperation Agency: Yokosuka, Japan, 1998; pp. 62-69.

23. Pereira, L. Edible Seaweeds of the World; Science Publishers, an Imprint of CRC Press/Taylor \& Francis Group: Boca Raton, FL, USA, 2016; p. 453. 
24. Pang, S.J.; Xiao, T.; Shan, T.F.; Wang, Z.F.; Gao, S.Q. Evidences of the intertidal red alga Grateloupia turuturu in turning vibrio parahaemolyticus into non-culturable state in the presence of light. Aquaculture 2006, 260, 369-374. [CrossRef]

25. Pérez, M.J.; Falqué, E.; Domínguez, H. Antimicrobial action of compounds from marine seaweed. Mar. Drugs 2016, 14, 52. [CrossRef]

26. Kavita, K.; Singh, V.K.; Jha, B. 24-branched delta 5 sterols from Laurencia papillosa red seaweed with antibacterial activity against human pathogenic bacteria. Microbiol. Res. 2014, 169, 301-306. [CrossRef]

27. Magallanes, C.; Córdova, C.; Orozco, R. Actividad antibacteriana de extractos etanólicos de macroalgas marinas de la costa central del Perú. Rev. Peru Biol. 2003, 2, 125-132. [CrossRef]

28. Pereira, L.; Mesquita, J.F. Population studies and carrageenan properties of Chondrachantus teedei var. lusitanicus (Gigartinaceae, Rhodophyta). J. Appl. Phycol. 2004, 16, 369-383. [CrossRef]

29. Valgas, C.; Machado, S.S.; Smânia, E.; Smânia, A. Screening methods to determine antibacterial activity of natural products. Braz. J. Microbiol. 2007, 38, 369-380. [CrossRef]

30. Pereira, L.; Sousa, A.; Coelho, H.; Amado, A.M.; Ribeiro-Claro, P.J.A. Use of FTIR, FT-Raman and 13C-NMR spectroscopy for identification of some seaweed phycocolloids. Biomol. Eng. 2003, 20, 223-228. [CrossRef]

31. Pereira, L.; Gheda, S.F.; Ribeiro-claro, P.J.A. Analysis by vibrational spectroscopy of seaweed with potential use in food, analysis by vibrational spectroscopy of seaweed polysaccharides with potential use in food, pharmaceutical, and cosmetic industries. Int. J. Carbohydr. Chem. 2013, 2013, 7. [CrossRef]

32. Soares, F.; Fernandes, C.; Silva, P.; Pereira, L. Antifungal activity of carrageenan extracts from the red alga Chondracanthus teedei var. lusitanicus. J. Appl. Phycol. 2016, 28, 2991. [CrossRef]

33. Pereira, L.; Amado, A.M.; Critchley, A.T.; Van de Velde, F.; Ribeiro-Claro, P.J.A. Identification of selected seaweed polysaccharides (phycocolloids) by vibrational spectroscopy (FTIR-ATR and FT-Raman). Food Hydrocoll. 2009, 23, 1903-1909. [CrossRef]

34. Kannan, S. FT-IR and EDS analysis of the seaweeds Sargassum wightii (brown algae) and Gracilaria corticata (red algae). Int. J. Curr. Microbiol. Appl. Sci. 2014, 3, 341-351.

35. Pereira, L. Therapeutic and Nutritional Uses of Algae, 1st ed.; Science Publishers' (SP), CRC Press/Taylor \& Francis Group: Boca Raton, FL, USA, 2018; p. 560.

36. Plaza, M.; Santoyo, S.; Jaime, L.; Reina, G.G.; Herrero, M.; Senõráns, F.J.; Ibáñez, E. Screening for bioactive compounds from algae. J. Pharm. Biomed. Anal. 2009, 51, 450-455. [CrossRef]

37. Pinteus, S.F.G. Avaliação da Capacidade Antioxidante e Antimicrobiana em Algas da Costa de Peniche (Portugal): Identificação de Compostos Bioactivos com Elevado Potencial Biotecnológico. Master's Thesis, Biotecnologia dos Recursos Marinhos, Instituto Politécnico de Leiria, Leiria, Portugal, 2011.

38. Jiang, Z.; Chen, Y.; Yao, F.; Chen, W.; Zhong, S.; Zheng, F.; Shi, G. Antioxidant, antibacterial and antischistosomal activities of extracts from Grateloupia livida (Harv). Yamada. PLoS ONE 2013, 8, e80413. [CrossRef]

39. Amorim, R.; Rodrigues, J.; Holanda, M.; Quinderé, A.; Paula, R.; Melo, V.; Benevides, N. Antimicrobial effect of a crude sulfated polysaccharide from the red seaweed Gracilaria ornata. Braz. Arch. Biol. Technol. 2012, 55, 171-181. [CrossRef]

40. Tan, S.P.; McLoughlin, P.; O'Sullivan, L.; Prieto, M.; Gardiner, G.; Lawlor, P.; Hughes, H. Development of a novel antimicrobial seaweed extract-based hydrogel wound dressing. Int. J. Pharm. 2013, 456, 10-20. [CrossRef] [PubMed]

41. Pierre, G.; Sopena, V.; Juin, C.; Mastouri, A.; Graber, M.; Maugard, T. Antibacterial activity of a sulfated galactan extracted from the marine alga Chaetomorpha aerea against Staphylococcus aureus. Biotechnol. Bioprocess Eng. 2011, 16, 937-945. [CrossRef]

42. Usov, A.I.; Miroshnikova, L.I.; Barbakadze, V.V. Polysaccharides of the algae. 17. Water-soluble polysaccharides of the red algae Grateloupia divaricata and Grateloupia turuturu. Zh. Obshch. Khim 1975, 45, 1583-1587. (In Russian)

43. Craigie, J.S. Cell walls. In The Biology of the Red Algae, 1st ed.; Cole, K.M., Sheath, R.G., Eds.; Cambridge University: New York, NY, USA, 1990; pp. 221-257. 
44. Denis, C.; Morancais, M.; Gaudin, P.; Fleurence, J. Effect of enzymatic digestion on thallus degradation and extraction of hydrosoluble compounds from Grateloupia turuturu. Bot. Mar. 2009, 52, 262-267. [CrossRef]

45. Pereira, M.G.; Benevides, N.M.B.; Melo, M.R.S.; Valente, A.P.; Melo, F.R.; Mourão, A.S. Structure and anticoagulant activity of a sulfated galactan from the red alga, Gelidium crinale. Is there a specific structural requirement for the anticoagulant action? Carbohydr. Res. 2005, 340, 2015-2023. [CrossRef] [PubMed]

(C) 2019 by the authors. Licensee MDPI, Basel, Switzerland. This article is an open access article distributed under the terms and conditions of the Creative Commons Attribution (CC BY) license (http://creativecommons.org/licenses/by/4.0/). 